Pavel POLACH ${ }^{1}$, Michal HAJŽMAN ${ }^{2}$

DOI: https://doi.org/10.53052/9788366249875.02

\title{
WYBRANE PROBLEMY ROZWOJU KONSTRUKCJI AUTOBUSÓW ROZWIĄZYWANE Z ZASTOSOWANIE SYMULACJI UKŁADÓW WIELOCZŁONOWYCH
}

\begin{abstract}
Streszczenie: W artykule omówiono najczęściej stosowane symulacje modeli obliczeniowych autobusów, w których stosuje się układy wieloczłonowe. Na początku, krótko omówiono problem dynamiki układów wieloczłonowych. A następnie, przedstawiono modele obliczeniowe dla testu łosia oraz czołowego uderzenia pojazdu poruszającego się z małą prędkością w betonową ścianę. Te sytuacje potraktowano, jako przykładowe podejścia do modelowania z zastosowaniem układów wieloczłonowych. Wyniki analiz takiego ujęcia modelowego oraz wyniki badań symulacyjnych przyczyniły się do rozwoju konstrukcji autobusów.
\end{abstract}

Słowa kluczowe: symulacja układów wieloczłonowych, autobus, manewrowanie pojazdem, test łosia, uderzenie z małą prędkością

\section{SELECTED PROBLEMS IN BUS DEVELOPMENT SOLVED USING MULTIBODY SIMULATIONS}

Summary: The paper deals with the most frequent simulations with the calculation models of buses based on multibody approaches. At first, the term multibody dynamics is introduced in brief. Then simulations of a moose test and slow front impact against the concrete wall are given as examples of using multibody simulations applied in bus development.

Keywords: multibody simulations, bus, driving manoeuvre, moose test, slow impact

\section{Introduction}

A vehicle (or a vehicle structure) is a complex (not only) mechanical system exposed to a long-time operational loading of a random character. The most suitable way how to achieve both technically and economically feasible solution that meets requirements for the operational strength and life of vehicles, their riding qualities,

\footnotetext{
${ }^{1}$ Research and Testing Institute Plzen, Czech Republic, polach@vzuplzen.cz

${ }^{2}$ Research and Testing Institute Plzen, Czech Republic, hajzman@vzuplzen.cz
} 
and comfort and passive safety of a driver and passengers is a combination of computational and experimental approaches (e.g. [1]). Multibody simulations (e.g. [2]), i.e. simulations generally meant for the investigation of kinematic quantities and dynamic behaviour of spatial constraint mechanical systems formed of the system of bodies are an important link of this chain of successive or mingling activities.

\section{On multibody dynamics in brief}

Multibody dynamics is based on physical models of real objects consisting of the systems of rigid and flexible bodies. These models enable to solve more general problems than the approaches based on the finite element method because they are independent of the continuous model of the investigated system. Computational models based on the system of bodies enable to introduce of general force applying and thus they are suitable for involving a wide range of both external and internal influences of a various characters (control, feedback, liquid, wind, variable gravitation).

Generally, multibody systems are formed of a definite number of bodies mutually coupled by kinematic pairs (or joints), constraints, and spring-damper elements. The bodies can move in space. Their motion is imposed by considered joints, constraints, spring-damper elements, the way of coupling to a frame (ground), and other boundary conditions. A rigid body is defined by inertia properties (mass, coordinates of the centre of gravity, and mass moments of inertia), a flexible body can be defined in more ways. Points are defined in the bodies. In the points the bodies can be coupled by joints (with zero to six degrees of freedom), by constraints, and by spring-damper elements. Further, in the points the bodies can be affected by external forces and torques. Generally, at creating a specific multibody model it must be considered which parts of the real object will be modelled by rigid or flexible bodies, how the bodies are mutually coupled and which of these couplings should be modelled by ideal joints, constraints and force applying.

After the multibody model creation it is possible to simulate its motion. When simulating the model motion it is necessary to generate (usually using the Lagrange method) nonlinear equations of motion, which are usually solved using numerical time integration. Commercial software programs generate those equations automatically and enable to choose from more methods of time numerical integration. Investigated quantities are kinematic (deflections, velocities and accelerations) and dynamic (forces and moments), viz. in joints, constraints, spring-damper elements, points, and bodies. (e.g. [3], [4]).

\section{Simulations with multibody models of buses}

Investigation of dynamic properties of vehicles using computer simulations is a theme of many professional publications. The problems of using multibody models in investigating dynamic properties of vehicles are globally solved e.g. in [5], [6], [7]. A smaller part of professional literature is aimed at buses, yet it is numerous. E.g. the authors are familiar with the themes of Polish colleagues, whose professional activities are focused on the investigation of dynamic properties of buses [8], [9], [10]. 
In [11] there are compared results of experimental measurements on a real bus with results of computer simulations performed with its multibody model created in the MSC.ADAMS software. In [12] driving properties of a bus are investigated with a multibody model created using flexible bodies. In [13] electric bus behaviour is analyzed for different driving situations in the MSC.ADAMS software. The same software is used in [14] for the evaluation of handling characteristics of an intercity bus. Driving comfort of a driver and passengers when driving along an uneven road surface with multibody bus models are investigated in [15] and [16].

It must be mentioned that financial costs of the development of road means of public transport, trucks, and semitrailers are always incomparably lower than costs of the passenger cars development. The above-mentioned types of road vehicles are always produced in lower series than passenger cars, which means that it is much worse to absorb the costs of their development in their production. It manifests not only at the stage of design but also at the support of solving potential technical problems during the vehicle operation. In the case of the multibody models' creation both insufficient quality and quantity of provided input data important for their creation are concerned in particular. It can result in less accurate and detailed multibody models than it would be optimum for the simulation of investigated operational situations. If some data important for a specific vehicle are not at disposal they are often taken over from a similar type of vehicle (e.g. [17], [18]).

It is evident that the aim of the simulations with multibody models of vehicles is the calculation of time histories and FFT results of time histories of kinematic and dynamic quantities providing information about the investigated properties of the vehicle during a selected operational situation.

In the case of buses, multibody models of an empty (i.e. of curb weight) and a fully loaded vehicle (i.e. of a gross vehicle weight rating), viz. a basic multibody model (multibody model with a simplified kinematic model of the axles suspension) and a more detailed multibody model (multibody model with a real kinematic model of the axles suspension) are usually created. The creation of relatively simple multibody models (in this case basic multibody models), which can be created without using commercial software, and an effort to put them more precisely is important especially for the reasons of considerable shortening of computing time and verification of correctness of the approach to the creation of the investigated object (in this case bus) model.

The most frequently performed simulations with the multibody models of buses are:

- driving manoeuvres (i.e. a severe double lane-change manoeuvre according to ISO 3888-1, moose test, steady-state skidpad driving, steady-state turning, steering returnability, braking in a curve, sudden steering-angle change according to ISO, sudden steering-angle change according to ESV, sinusoidal steering-wheel input, random steering-wheel input, and traffic lane change; results provide information on the vehicle driving properties),

- driving operations (i.e. braking, acceleration; results inform about the vehicle driving properties),

- $\quad$ running over an artificial obstacle (outputs of time histories of dynamic forces in the axle suspension elements are input data for the calculation of the body, and chassis parts strain using software based on the FEM method, time dependencies of relative deflections of air springs, and rates of rebound and compression of 
shock absorbers inform about the suitability of the used axle suspension elements),

- $\quad$ driving along an uneven road surface (results can be used for the evaluation of fatigue life of dynamically loaded vehicle parts, and are often used for the evaluation of driving comfort of a driver and passengers),

- a slow front impact against a concrete wall (results are input data for the evaluation of the vehicle structure deformation using the FEM programs),

- $\quad$ influence of lateral wind (results provide information about the vehicle driving stability).

Further, the results of the simulations with the multibody models of buses can be used for the evaluation of passive safety of a driver and passengers.

The set of results of the simulations of various operational situations can confirm the suitability or, on the contrary, reveal shortcomings of the vehicle design (from the point of view of its kinematic and dynamic properties).

\subsection{Experimental and computational investigation of handling behaviour of the TriHyBus}

The TriHyBus (abbreviation of the Triple Hybrid Hydrogen Bus) project comprised research and development, implementation and a test operation of a city bus (see Figure 1) with hybrid electric propulsion using hydrogen fuel cells (e.g. [18]). The mass distribution and the total bus mass are rather different from common buses. This is the reason for investigating the bus driving stability. In order to obtain a tool for dynamic analysis, a multibody model of the bus was created (see Figure 2). The aim of the simulations with the verified bus multibody models is the calculation of kinematic and dynamic quantities giving information about the investigated properties of the vehicle at the selected operational situation. E.g. severe double lane-change manoeuvres according to ISO 3888-1 and moose tests were performed with a real vehicle.

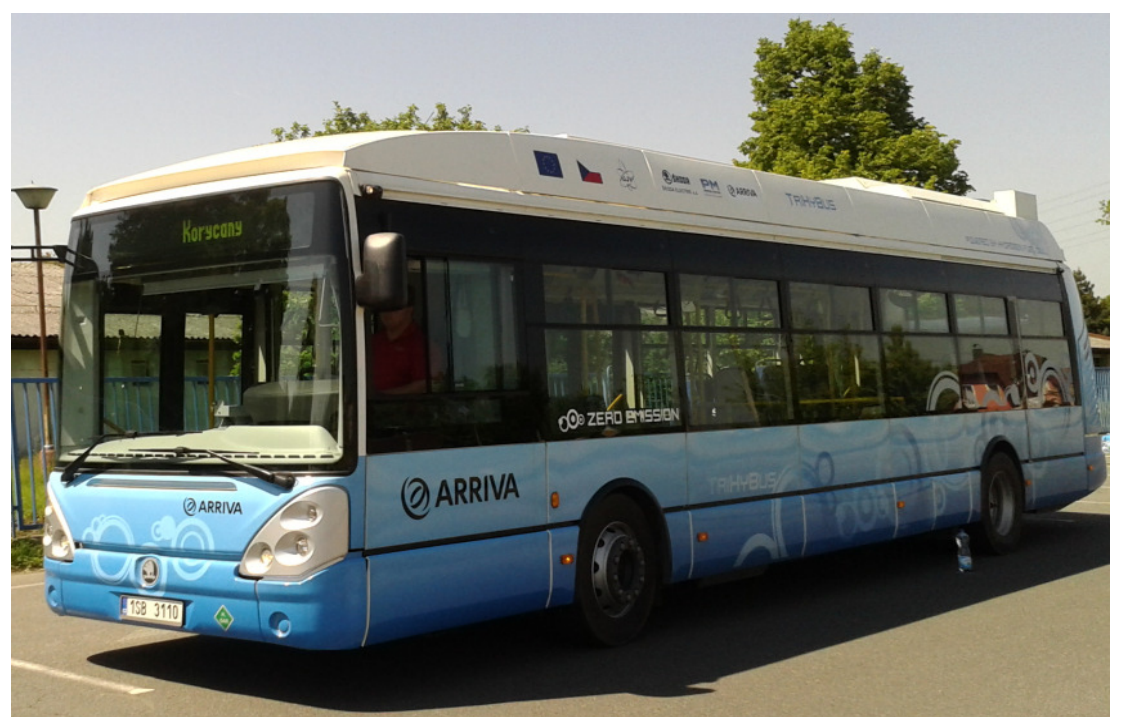

Figure 1. The TriHyBus - the real vehicle 


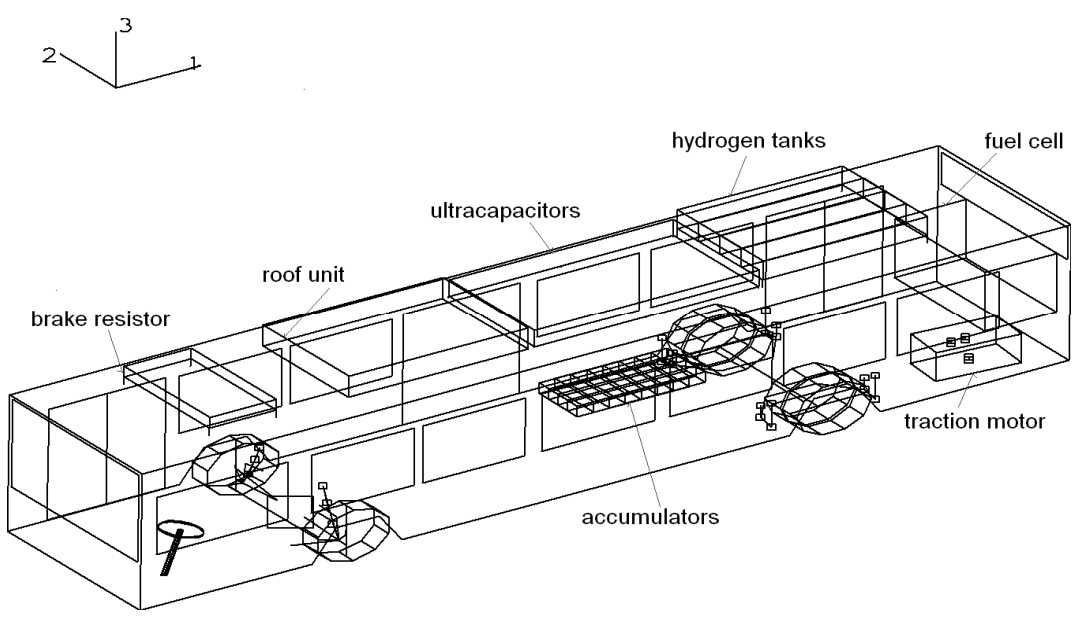

Figure 2. The TriHyBus - the multibody model visualization in alaska 2.3 simulation tool

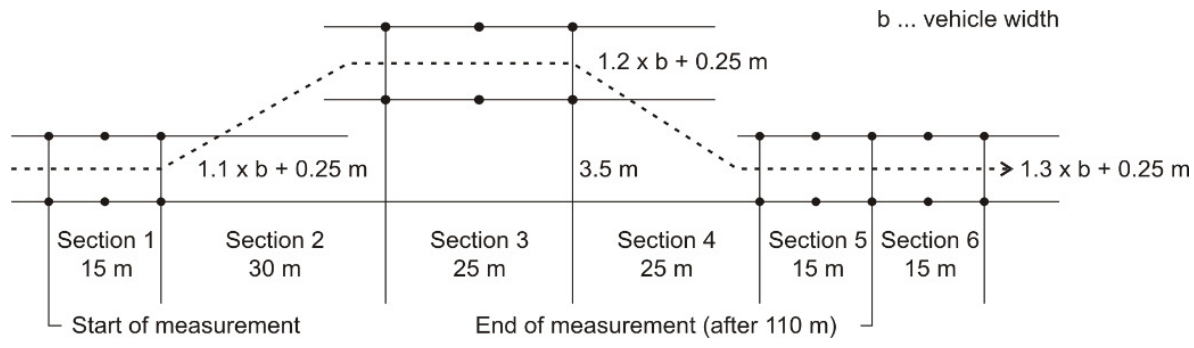

Figure 3. Scheme of the test track for the severe double lane-change manoeuvre according to ISO 3888-1 (taken from [19])

The severe double lane-change manoeuvre according to ISO 3888-1 is a widespread testing method for a subjective evaluation of the dynamic properties of road vehicles. The scheme of the test track can be seen in Figure 3. The overall track length in case of the double lane-change manoeuvre according to ISO $3888-1$ is $125 \mathrm{~m}$, and the individual track sections width is dependent on the vehicle width (width of the TriHyBus is $b=2.5 \mathrm{~m}$ ).

The moose test is a test used to determine the vehicle behaviour at a severe lanechange manoeuvre to avoid an unexpected obstacle. In Sweden, this test has been used for many decades, because a moose is the most frequent unexpected obstacle there and a collision with it is tragic for travellers in most cases. The track, which must be driven through during this test, is schematically drawn in Figure 4.

Both tests are performed on the smooth surface of a horizontal road. The vehicle must travel with a predefined speed before entering the test section and after having driven through it must brake down. That is why the area, in which the testing manoeuvres are performed, must be sufficiently long. The maximum speed of driving through the 
test track without knocking down the cone outlining the track is evaluated during the tests. The fact that the maximum speed of the tested vehicle is sufficient can be evaluated based on the comparison with another vehicle of a similar type or the requirements of its potential operators.

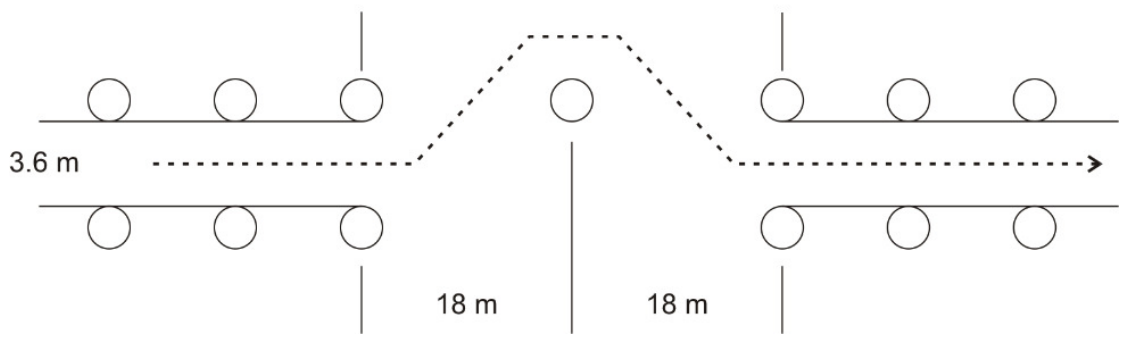

Figure 4. Scheme of the moose test track

In comparison with the previous experimental measurements on similar vehicles much more utilizable data were recorded for performing simulations of driving manoeuvres with multibody models and their verification. From the point of view of simulations with the TriHyBus multibody model, the measured bus speed and bus trajectory were the quantities for defining input data of the test drives.

Selected quantities recorded during the testing manoeuvres (those, which the TriHyBus producer was interested in) were the time histories of relative deflections of the right air spring before the rear axle. (see Figure 5), time histories of relative deflections of the left air spring before the rear axle (see Figure 6), time histories of roll angle (see Figure 7) around the longitudinal axis (around axis "1" - see Figure 2), and time histories of yaw angle (see Figure 8) around the vertical axis (around axis "3" - see Figure 2).

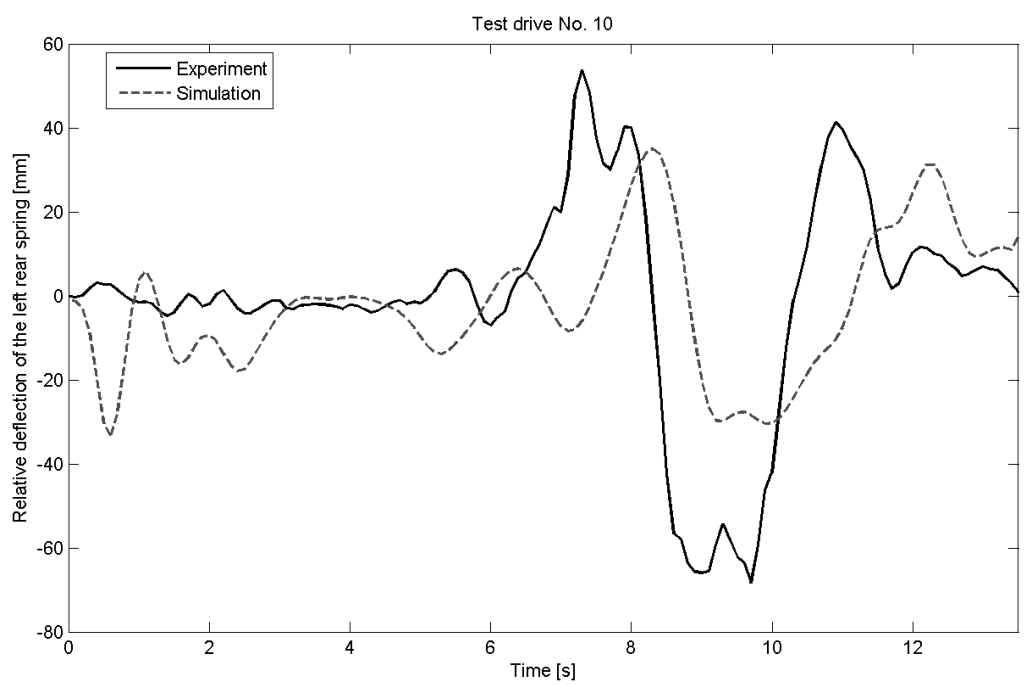

Figure 5. Time histories of relative deflection of the left spring before the rear axle at the moose test (at average vehicle speed approx. $35 \mathrm{~km} / \mathrm{h}$ ) (taken from [18]) 


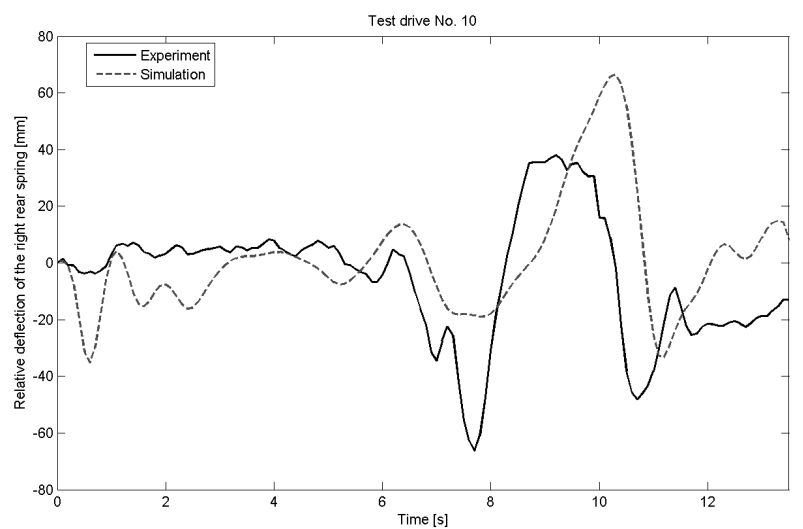

Figure 6. Time histories of relative deflection of the right spring before the rear axle at the moose test (at average vehicle speed approx. $35 \mathrm{~km} / \mathrm{h}$ ) (taken from [18])

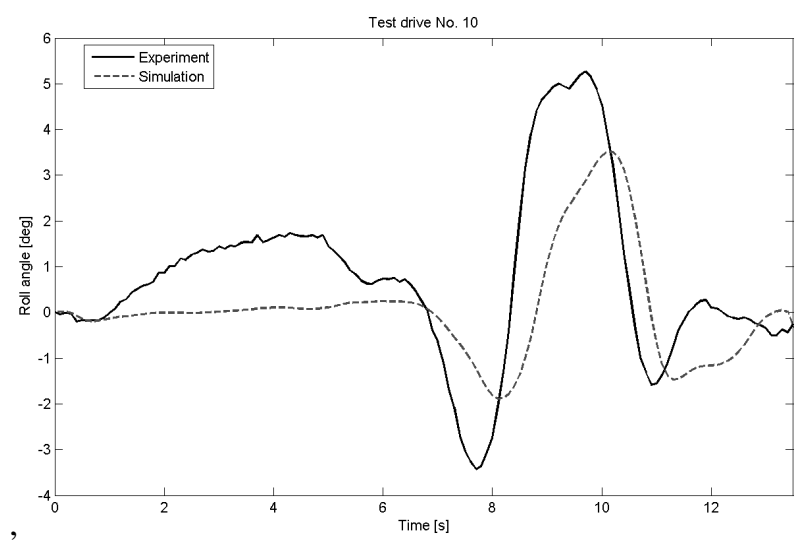

Figure 7. Time histories of the vehicle roll angle at the moose test (at average vehicle speed approx. $35 \mathrm{~km} / \mathrm{h}$ ) (taken from [18])

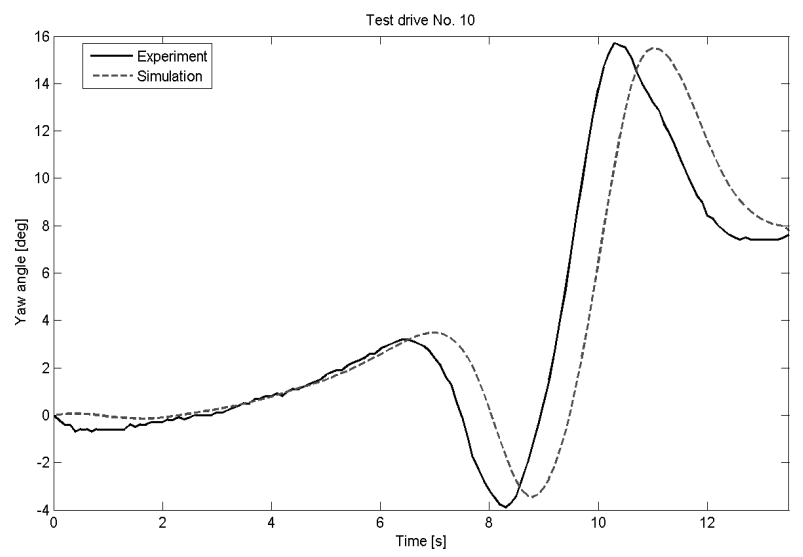

Figure 8. Time histories of the vehicle yaw angle at the moose test (at average vehicle speed approx. $35 \mathrm{~km} / \mathrm{h}$ ) (taken from [18]) 
Based on comparing the simulations results and the results of experimental measurements it is evident that a certain coincidence of results exists. The not completely perfect coincidence of the results is influenced mostly by the ignorance of the actual air pressure in air springs of the bus suspension. In the case of further possible test drives with the real TriHyBus it will be necessary to measure the pressure in the air springs due to defining multibody models more precisely.

\subsection{Simulations of slow front impact against the concrete wall}

The front impact against a concrete wall at the running speed of $5 \mathrm{~km} / \mathrm{h}$ is one of the tests which are used for the verification of properties of public transport vehicles required by their keepers. In practice, a slow front impact may occur e.g., during arrival in the bus depot. Due to that impact, a permanent deformation of the vehicle structure should not occur. This requirement was a starting point for the proposal of the new design of a front wall of the ŠKODA buses (Czech bus producer) in which a new type of bumper was used. The simulations of a slow front impact were carried out with the buses multibody models [20].

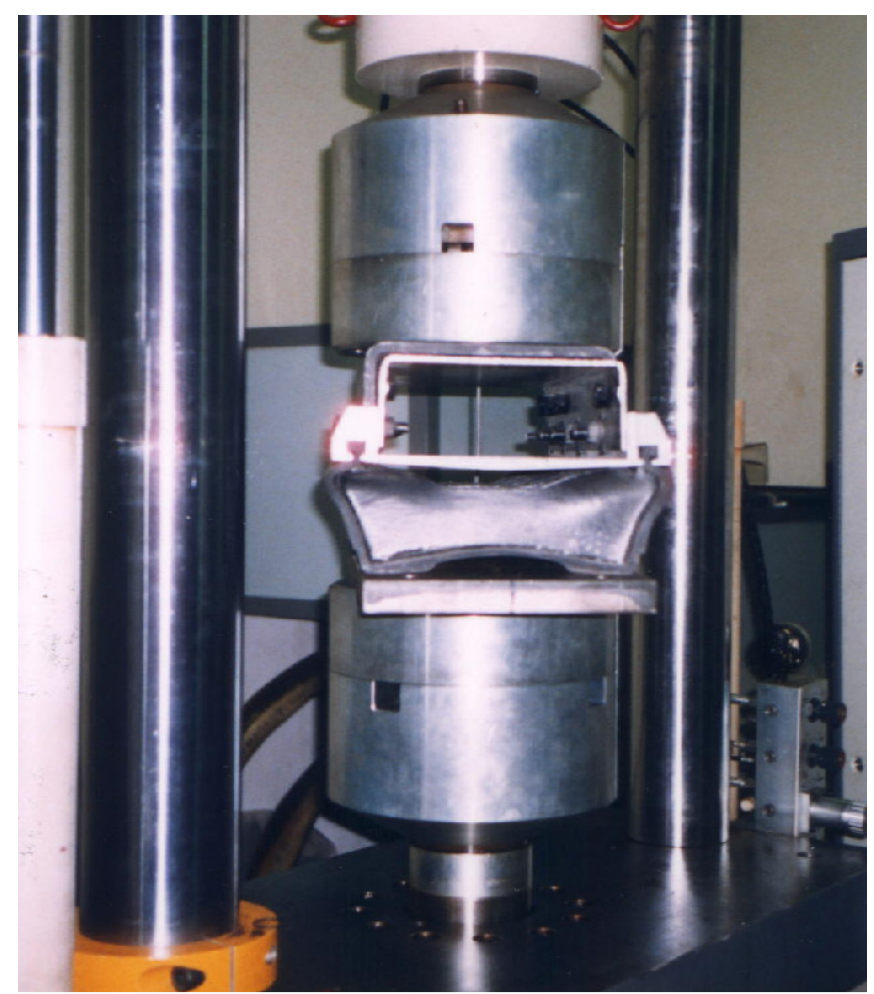

Figure 9. Laboratory measurement of the loading characteristics of a bumper

Loading characteristics of the bumper, experimentally measured in the Accredited Dynamic Testing Laboratory of Research and Testing Institute Plzen on the SCHENCK $400 \mathrm{kN}$ hydraulic loading machine (see Figure 9), were used in the buses multibody models (see Figure 10). 


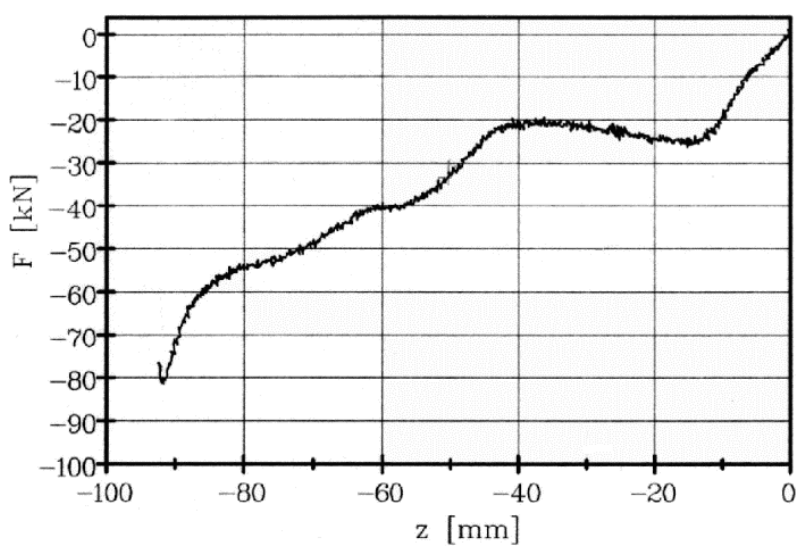

Figure 10. Measured characteristics of the bumper

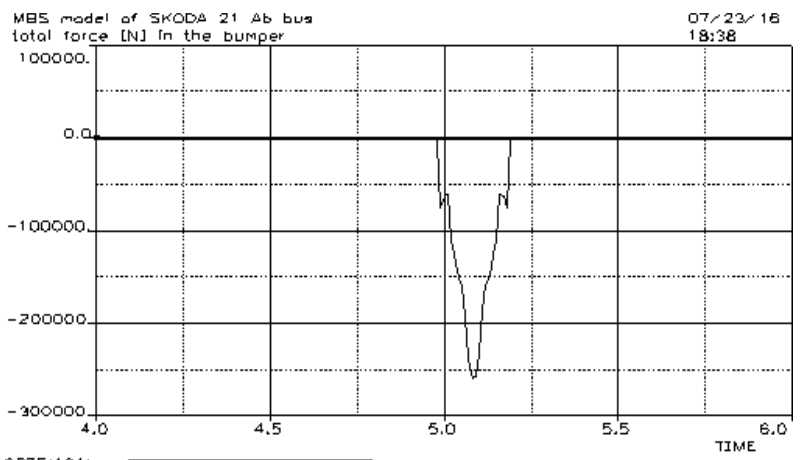

SDTF(21)

Figure 11. Time history of the force [N] transferred to the front wall of the ŠKODA 21 Ab bus

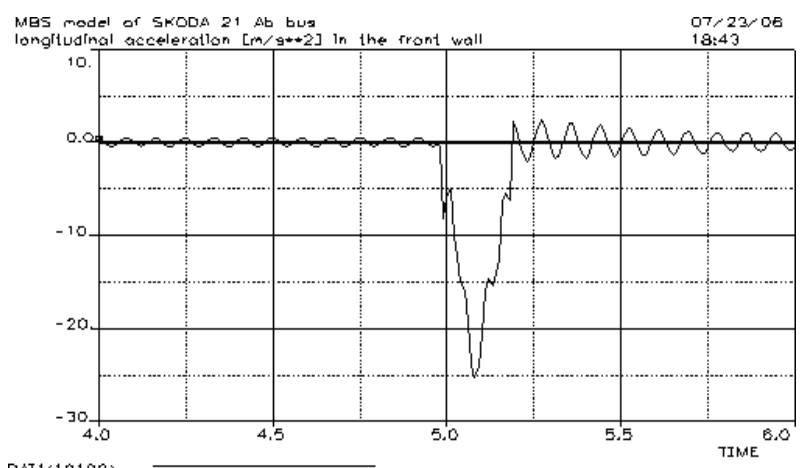

PAT1 (10100)

Figure 12. Time history of the longitudinal acceleration $\left[\mathrm{m} / \mathrm{s}^{2}\right]$ in the front wall of the ŠKODA 21 Ab bus

Time histories and extreme values of the bumper deformation, of the acceleration in the front wall of the buses and of the total force transferred to the front wall of the buses were the monitored quantities during slow front impact simulations. The 
simulations results served as input data for the FEM calculation of the buses structure deformation. Selected results of the slow front impact against a concrete wall simulation are given in Figures 11 and 12 for the ŠKODA 21 Ab bus.

\section{Conclusions}

To verify the correctness of the results of computer simulations with the virtual model it is important to validate them with the evaluation of experimental measurements on the real structure. Both approaches support and complement each other (e.g. [1]). It is possible to use the results of experimental measurements for defining a virtual model more precisely (e.g. [1], [18]). On the contrary, the results of computer simulations reveal other critical points of the structure, to which attention should be paid during experimental measurements. This mutual improving experimental and computer approaches lead to better identification of the structural properties and thus to the possibility of more qualified evaluation of possible design modifications.

\section{Acknowledgements}

The paper has originated in the framework of institutional support for the long-time conception development of the research institution provided by the Ministry of Industry and Trade of the Czech Republic to Research and Testing Institute Plzen.

\section{REFERENCES}

1. KEPKA M., POLACH P.: Testing and Computing of Vehicles in SKODA VYZKUM. Proc. Combined Conf. on Heavy Vehicles XXXVI. Meeting of Bus and Coach Experts and Congress on Commercial Vehicles, Budapest 2005, CD-ROM.

2. KEPKA M., HEJMAN M., POLACH P., VÁCLAVÍK J.: Using the Computer Simulations at Trolleybus Development: Strength, Dynamic and Fatigue. Proc. European Conf. on Computational Mechanics '99, Munich 1999, CD-ROM.

3. STEJSKAL V., VALÁŠEK M.: Kinematics and Dynamics of Machinery. Marcel Dekker, Inc., New York 1996.

4. AWREJCEWICZ J.: Classical Mechanics: Dynamics. Springer, New York 2012.

5. GENTA G., MORELLO L.: The Automotive Chassis, Volume 2: System Design. Springer Science+Business Media B.V., 2009.

6. BLUNDELL M., HARTY D.: The Multibody Systems Approach to Vehicle Dynamics. Elsevier Butterworth-Heinemann, Oxford 2004.

7. POPP K., SCHIEHLEN W.: Ground Vehicle Dynamics. Springer-Verlag, Berlin Heidelberg 2010.

8. KOWARSKA I., KORTA J., KUCZEK K., UHL T.: Hybrid Modelling of an Urban Bus. Mechanics and Control, 32(2013)1, 13-20.

9. KOWARSKA I., KORTA J., KUCZEK K., UHL T.: Fully Equipped Dynamics Model of a Bus. Shock and Vibration 2014, ID 201952. 
10. KOWARSKA I., SKRABEK J., KUCZEK K., UHL T.: Model-based engineering - simulations based design of the suspension of city bus. Journal of KONES Powertrain and Transport, 18(2011)4, 205-212.

11. PRADO M., CUNHA R. H., NETO Á. C., COSTA A., MANCOSU F., SAVI C., D’ELBOUX J. E.: Bus Handling Analysis and Experimental Validation Using the Multibody System Technique. Proc. of SAE Brazil 2001 Congress and Exhibit. São Paulo 2001, SAE Paper 2001-01-3966.

12. GEORGIOU G., BADARLIS A., NATSIAVAS S.: Modelling and ride dynamics of a flexible multi-body model of an urban bus. Proceedings of the Institution of Mechanical Engineers, Part K: Journal of Multi-body Dynamics, 222(2008)2, 143-154.

13. TEIXEIRA R. R., MOREIRA, S. R. D. S., TAVARES, S. M. O.> Multibody dynamics simulation of an electric bus. Procedia Engineering, 114(2015), 470477.

14. MURTHY S. S., GOWDA M. M. H., VENNA H. K.: Evaluation of Handling Characteristics of an Intercity Bus by Multi-Body Dynamic Simulations. Proc. Inter. Mobility Conf., 2016, SAE Technical Paper 2016-28-0178.

15. SEKULIĆ D., DEDOVIĆ V.: Intercity bus users vibration comfort analysis through an oscillatory model with seven DOF using ADAMS/VIEW software. Journal of Applied Engineering Science, 9(2011)3, 401-410.

16. SEKULIČ D., DEDOVIĆ V., RUSOV S., ŠALINIĆ S., OBRADOVIĆ A.: Analysis of vibration effect on the comfort of intercity bus users by oscillatory model with ten degrees of freedom. Applied Mathematical Modelling, 37(2013), 8629-8644.

17. POLACH P., VÁCLAVÍK J.: Investigation of Lateral Dynamics of Triple Hybrid Hydrogen Bus. Proc. 11th Inter. Conf. on Vibration Problems, Lisbon 2013, USB flash drive.

18. POLACH P., VÁCLAVÍK J.: Experimental and Computational Investigation of Handling Behaviour of Hydrogen Bus. Journal of Vibration Engineering \& Technologies, 4(2016), 259-270.

19. http://www.handling.cz/stranky/isotest_en.htm, 01.08.2016.

20. POLACH P.: Ten Years of Multibody Simulations in ŠKODA VÝZKUM. Proc. 22nd conf. with inter. participation Computational Mechanics 2006, Hrad Nečtiny 2006, I 3-16. 
